\title{
Erratum to "Short communication: Teat-end shape and udder-level milking characteristics and their associations with machine milking-induced changes in teat tissue condition" (J. Dairy Sci. 101:11447-11454)
}

\section{Wieland, D. V. Nydam, N. Älveby, P. Wood, and P. D. Virkler}

A sentence was omitted from the first paragraph. The final two sentences of the first paragraph should read (deleted sentence in bold): "However, associations between teat characteristics such as teat-end shape and machine milking-induced short-term changes have not been investigated by rigorous methods. The primary objective of this study, therefore, was to investigate the association of teat-end shape with visually assessed machine milking-induced short-term changes using the scoring system according to Hillerton et al. (2000).

The journal regrets the error.

\section{REFERENCES}

Wieland, M., D. V. Nydam, N. Älveby, P. Wood, and P. D. Virkler. 2018. Short communication: Teat-end shape and udder-level milking characteristics and their associations with machine milking-induced changes in teat tissue condition. J. Dairy Sci. 101(12):11447-11454. 